\title{
Ribeiro's typology, genomes, and Spanish colonialism, as viewed from Gran Canaria and Colombia
}

\author{
Maria Cátira Bortolini ${ }^{1,2}$, Mark G. Thomas ${ }^{1}$, Lounes Chikhi ${ }^{1}$, Juan A. Aguilar ${ }^{1}$, \\ Dinorah Castro-De-Guerra ${ }^{3}$, Francisco M. Salzano ${ }^{2}$ and Andres Ruiz-Linares ${ }^{1}$ \\ ${ }^{1}$ University College London, Department of Biology, London, United Kingdom. \\ ${ }^{2}$ Universidade Federal do Rio Grande do Sul, Departamento de Genética, Porto Alegre, RS, Brazil. \\ ${ }^{3}$ Instituto Venezolano de Investigaciones Científicas, Laboratorio de Genética Humana, Caracas, Venezuela.
}

\begin{abstract}
Four biallelic and six multiallelic Y-chromosome polymorphisms were investigated in 59 Gran Canarian, 60 North African Berber and 46 Spanish subjects. These new data were merged with equivalent literature information to obtain the parental Y-chrosomomal contribution in Gran Canarians, Colombians, and Venezuelans. The results were then compared, for Gran Canarians and Colombians, to those derived from autosomal and mtDNA. In both groups, the Spanish Y-chromosome contribution was much more marked than that estimated using mtDNA. This analysis showed a usual trend in the Spanish Colonial history, characterized by a demographic collapse of the aboriginal population, but with considerable introgression of genes through native women. In accordance to D. Ribeiro's typology for peoples subjected to Colonialism, the Y-chromosomes of these admixed populations are classified as transplanted, their mtDNA as witness, and their autosome sets as new.
\end{abstract}

Key words: Gran Canaria, Y-chromosome polymorphisms, admixture.

Received: April 14, 2003; Accepted: September 8, 2003.

\section{Introduction}

The great adventure of the maritime colonial expansion promoted by Europeans during the $15^{\text {th }}$ and $16^{\text {th }}$ centuries considerably changed their history and that of the other continents. The socio-cultural impact of this event has already been determined, but only more recently have the genetic aspects related to it been evaluated (Salzano and Bortolini, 2002). Present-day American populations which are directly related to this relatively recent historical event can be classified, according to Ribeiro $(1970,1977)$ as witness, new, transplanted and emergent peoples. Recently, we coined the expression transplanted male genome for the event of substitution of native Y-chromosomes in South America (Castro-de-Guerra et al., 2003).

The Canarian archipelago is located in the Atlantic Ocean off the southern coast of Morocco and comprises seven islands: El Hierro, La Palma, La Gomera, Fuenteventura, Lanzarote and the main islands of Tenerife and Gran Canaria. The first inhabitants of these islands arrived around the middle of the second millennium $\mathrm{BC}$, and an-

Send correspondence to Maria Cátira Bortolini. Universidade Federal do Rio Grande do Sul, Departamento de Genética, Caixa Postal 15053, 91501-970 Porto Alegre, RS, Brazil. E-mail: maria.bortolini@ufrgs.br. thropological studies indicate a close relationship between these early colonizers and the North African Berbers, although this aboriginal population was probably not a homogeneous group (Murdock, 1959; Schwidetzky, 1963; Velasco-Vásquez et al., 1999; Flores et al., 2003). Although the Greeks and Romans explored the Canary Islands (giving them that name), it was not until the 15 th century that the archipelago was settled by Europeans, when it was incorporated into the expanding Spanish Empire. Following the colonial settlement, the native population of the Islands (known as Guanche) declined from an estimated 60,000 at the time of first contact to complete extinction in our days (Fernandez-Armesto, 1982).

Despite the disappearance of the Guanche, genetic studies indicate that the population of the Canarian archipelago shows evidence of North African admixture, which most likely reflects intermarriage between natives and immigrants early in the colonial period (Esteban et al., 1998). Classical markers (blood groups and proteins) suggest that the genetic background of the current Canary Islanders as a whole is about $71 \%$ Spanish, 21\% North African, and 8\% Sub-Saharan African (Flores et al., 2001). Studies of the maternally inherited mitochondrial DNA (mtDNA) and paternal Y-chromosome markers indicate a considerably smaller and higher Spanish contribution, respectively 
(Flores et al., 2001, 2003), suggesting a highly asymmetric mating pattern after the European occupation. The SubSaharan African ancestry most likely reflects admixture with African slaves, considering that, during the colonial period, the Spanish forcibly introduced some 25,000 individuals (mostly from West Africa) into Madeira, Cape Verde and the Canarian Islands (Curtin, 1969).

We present here data obtained from the investigation of 4 biallelic and 6 multiallelic Y-chromosome markers in samples from the island of Gran Canaria, from Spain and from North African Berbers. This new genetic data set was analyzed in conjunction with other relevant data from the literature. Additionally, we compared our results with those obtained with the same Y-chromosome markers in Colombia and Venezuela, both former Spanish colonies. Our results show a noticeable Guanche (Berber) contribution at the Y-chromosome level in Gran Canaria, while a SubSaharan African ancestry is negligible, in agreement with previous inferences using other sets of Y-chromosome markers. Additionally, we extended Ribeiro's $(1970,1977)$ typology to characterize the genomes of these admixed populations.

\section{Subjects and Methods}

\section{Populations studied}

Blood samples or oral swabs were collected from unrelated voluntary men from the Island of Gran Canaria (Las Palmas, $\mathrm{N}=59$ ), mainland Spain (Barcelona, $\mathrm{N}=24$; Valencia, $\mathrm{N}=22$ ) and from Moroccan Berbers (Ifani ethnic group, $\mathrm{N}=60$ ). The individuals from Barcelona had no Catalonian ancestry, but rather originated in various Spanish regions. Genomic DNA was extracted using the Nucleon extraction kit according to the manufacturer's instructions.

\section{DNA markers typed}

The strategy adopted for assessing the male ancestry of our Gran Canarian sample was to contrast results for biallelic and multiallelic markers. This should allow an approximation to the effect of marker polymorphism on the estimation of admixture. Y-chromosome haplogroups were defined by typing the following biallelic or SNP (single nucleotide polymorphism) markers: DYS271 (Hammer and Horai, 1995), DYS287 (Seielstad et al., 1994), M9 (Underhill et al., 1997), and 92R7 (Hurles et al., 1998). These SNPs were selected based on their important allele frequency differentials in the putative parental populations of the Canary Islands (European, North African Berber and Sub-Saharan African; Underhill et al. 2000, 2001), thus potentially being the most informative biallelic markers for assessing ethnic ancestry on the island. The aim was not to establish a fine-grained SNP-Y-chromosome phylogeny, but rather to apportion the diversity observed on Gran Canaria into its three major possible ancestral lineages.
Multiallelic marker data were obtained by typing microsatellites DYS19, DYS388, DYS390, DYS391, DYS392, and DYS393. This set of markers has been used in numerous other studies (Thomas et al., 2000; Carvajal-Carmona et al., 2000; Bortolini et al., 2003; Kayser et al., 2003), and specifically DYS19 and DYS393 had been tested in Canarians by Flores et al. (2003). The other four markers (DYS19, DYS388, DYS390, and DYS392) were never investigated in a Canarian sample. They were typed using the experimental conditions reported by Thomas et al. (1999). Following common usage, we refer to biallelic lineages as haplogroups, to distinguish them from microsatellite marker haplotypes. Haplogroup nomenclature is based on YCC (Y Chromosome Consortium, 2002) recommendations.

\section{Data analysis}

The ARLEQUIN 2000 computer package (Schneider et al., 2000) was employed to obtain the six-locus microsatellite haplotype frequencies. Admixture was estimated by Long's (1991) method, using the ADMIX program kindly provided by the author.

\section{Results and Discussion}

We grouped our Gran Canaria, Berber and Spanish data set (Appendix) with other information from the literature. Table 1 summarizes the frequency of $\mathrm{Y}$-chromosome haplogroups in Gran Canarians and their presumed parental populations (Spanish, North African Berber and SubSaharan African), as well as in two South American populations from areas of early Spanish colonial influence (Colombia and Venezuela). The Native American group was also included, since it is a putative parental population of Colombians and Venezuelans. Haplogroup P-92R7* is a good indicator of Spanish ancestry, as it reaches a frequency of $80 \%$ in Spain, while it is rare in the other putative parental populations. Similarly, haplogroups DE-YAP*, E-M2 and Q-M3 are good indicators of North African Berber, Sub-Saharan African and Native American ancestry, as they reach frequencies of respectively $83 \%, 63 \%$ and $85 \%$ in those populations and low frequencies elsewhere. Haplogroup Y* (ancestral to all SNP markers typed here) is less informative in that it has a largely uniform distribution across the parental populations compared, with the exclusion of Native Americans. In Gran Canarian chromosomes, P-92R7* and DE-YAP* were found at frequencies of $62 \%$ and $17 \%$ respectively, while the frequency detected for E-M2 was low (1\%), suggesting a negligible Sub-Saharan African contribution. Comparable frequencies were found in Colombia and Venezuela.

Table 2 lists the six-locus microsatellite haplotypes detected in Gran Canarians, as well as in Spaniards and North African Berbers, grouped according to their biallelic lineage background. About $47 \%$ of the haplotypes, which represent $63 \%$ of the chromosomes seen in Gran Canarians, are present in Spanish or Berber subjects. None of the Gran 
Table 1 - Y-chromosome biallelic haplogroups and their frequency in Gran Canarians and other human populations.

\begin{tabular}{|c|c|c|c|c|c|}
\hline \multirow[t]{3}{*}{ Population } & \multicolumn{5}{|c|}{ SNP-Haplogroup } \\
\hline & P-92R7* & $\mathrm{Y}^{*}$ & DE-YAP** & E-M2 & Q-M3 ${ }^{6}$ \\
\hline & \multicolumn{5}{|c|}{ Frequency (\%) } \\
\hline Gran Canarians $(\mathrm{N}=137)^{1}$ & 62 & 20 & 17 & 1 & NT \\
\hline Colombians $(\mathrm{N}=80)^{2}$ & 58 & 33 & 4 & 4 & 1 \\
\hline Venezuelans $(\mathrm{N}=53)^{3}$ & 65 & 26 & 9 & 0 & 0 \\
\hline Spanish $(N=124)^{1}$ & 80 & 15 & 5 & 0 & NT \\
\hline North African Berbers $(\mathrm{N}=104)^{1}$ & 2 & 11 & 83 & 4 & NT \\
\hline Sub-Saharan Africans $(N=56)^{4}$ & 0 & 12 & 25 & 63 & NT \\
\hline Native Americans $(356)^{5}$ & 11 & 2 & 1 & 1 & 85 \\
\hline
\end{tabular}

${ }^{1}$ The samples include individuals typed by us (59 Canarians, 60 North African Berbers, and 46 Spanish) and data (78 Gran Canarians, 44 North African Berbers, and 78 Spanish) reported by Pérez-Lezaun et al. (1997), Bosch et al. (1999), and Flores et al. (2003).

${ }^{2}$ Samples collected in Medellín (Carvajal-Carmona et al., 2000).

${ }^{3}$ Samples obtained from individuals living in three small communities located near Caracas, basically founded by Spanish-Canarian families at the end of the seventeenth and nineteenth centuries (Castro-de-Guerra et al., 2003).

${ }^{2,3}$ The individuals could be classified as white (L. Carvajal-Carmona and D. Castro-de-Guerra, personal communication).

${ }^{4}$ Hammer et al. (1997).

${ }^{5}$ Bortolini et al. (2002).

${ }^{6}$ The DYS199-T mutation, which defines this haplogroup, was not tested in the Gran Canarian, African and European samples, but earlier results indicate that it is restricted to Amerindians and a few populations of northeast Siberia. To stress the testing differences, 0 was employed when the DYS199-T mutation was searched and not found, while NT (not tested) indicates that such tests had not been performed. The assumption of Q-M3 absence in the indicated groups, used for the present admixture study, is validated by analyses such as those performed by Underhill et al. (2000).

Table 2 - Y-chromosome microsatellite haplotype frequencies in Spain, Gran Canaria and North African Berbers ${ }^{1}$.

\begin{tabular}{|c|c|c|c|c|c|c|c|c|c|}
\hline \multirow[t]{2}{*}{ Haplotype } & \multicolumn{6}{|c|}{ Loci $^{2}$} & \multicolumn{3}{|c|}{ Population } \\
\hline & 1 & 2 & 3 & 4 & 5 & 6 & $\begin{array}{l}\text { Spain } \\
(124)\end{array}$ & $\begin{array}{c}\text { Gran Canaria } \\
(59)\end{array}$ & $\begin{array}{c}\text { Berbers } \\
(104)\end{array}$ \\
\hline \multicolumn{10}{|c|}{ P-92R7* haplogroup } \\
\hline 1 & 14 & 12 & 24 & 11 & 13 & 13 & 0.174 & 0.168 & \\
\hline 2 & 14 & 12 & 24 & 10 & 13 & 13 & 0.137 & 0.067 & \\
\hline 3 & 14 & 12 & 23 & 11 & 13 & 13 & 0.016 & 0.051 & \\
\hline 4 & 15 & 12 & 24 & 11 & 13 & 13 & 0.024 & 0.034 & \\
\hline 5 & 15 & 12 & 23 & 11 & 13 & 13 & 0.024 & 0.017 & \\
\hline 6 & 15 & 12 & 24 & 10 & 13 & 13 & 0.008 & 0.017 & \\
\hline 7 & 14 & 13 & 24 & 10 & 13 & 13 & 0.008 & 0.017 & \\
\hline 8 & 14 & 12 & 25 & 10 & 13 & 13 & 0.016 & 0.017 & \\
\hline 9 & 14 & 12 & 25 & 11 & 13 & 14 & 0.008 & 0.017 & \\
\hline 10 & 14 & 12 & 24 & 10 & 11 & 13 & 0.040 & & \\
\hline 11 & 14 & 13 & 23 & 10 & 11 & 12 & 0.008 & & \\
\hline 12 & 14 & 12 & 24 & 11 & 11 & 13 & 0.089 & & \\
\hline 13 & 14 & 12 & 25 & 11 & 13 & 13 & 0.032 & & \\
\hline 14 & 14 & 12 & 23 & 10 & 13 & 13 & 0.024 & & \\
\hline 15 & 14 & 12 & 23 & 11 & 13 & 14 & 0.016 & & \\
\hline 16 & 14 & 17 & 24 & 10 & 11 & 12 & 0.008 & & \\
\hline 17 & 14 & 17 & 24 & 11 & 13 & 13 & 0.008 & & \\
\hline 18 & 13 & 12 & 24 & 10 & 13 & 13 & 0.008 & & \\
\hline 19 & 14 & 12 & 25 & 10 & 13 & 12 & 0.008 & & \\
\hline 20 & 14 & 12 & 23 & 10 & 13 & 14 & 0.008 & & \\
\hline 21 & 13 & 12 & 25 & 10 & 13 & 12 & 0.008 & & \\
\hline 22 & 14 & 12 & 24 & 12 & 13 & 13 & 0.008 & & \\
\hline 23 & 15 & 12 & 23 & 10 & 11 & 13 & 0.008 & & \\
\hline 24 & 14 & 12 & 23 & 10 & 11 & 13 & 0.008 & & \\
\hline 25 & 14 & 12 & 23 & 11 & 14 & 14 & 0.008 & & \\
\hline 26 & 14 & 12 & 24 & 11 & 12 & 12 & 0.008 & & \\
\hline 27 & 14 & 12 & 24 & 10 & 11 & 14 & 0.008 & & \\
\hline
\end{tabular}


Table 2 (cont.)

\begin{tabular}{|c|c|c|c|c|c|c|c|c|c|}
\hline \multirow[t]{2}{*}{ Haplotype } & \multicolumn{6}{|c|}{ Loci $^{2}$} & \multicolumn{3}{|c|}{ Population } \\
\hline & 1 & 2 & 3 & 4 & 5 & 6 & $\begin{array}{l}\text { Spain } \\
(124)\end{array}$ & $\begin{array}{c}\text { Gran Canaria } \\
(59)\end{array}$ & $\begin{array}{c}\text { Berbers } \\
(104)\end{array}$ \\
\hline 28 & 15 & 12 & 23 & 11 & 13 & 14 & 0.008 & & \\
\hline 29 & 14 & 13 & 24 & 11 & 13 & 13 & 0.008 & & \\
\hline 30 & 15 & 12 & 22 & 9 & 11 & 13 & 0.008 & & \\
\hline 31 & 15 & 12 & 24 & 11 & 13 & 12 & 0.008 & & \\
\hline 32 & 14 & 12 & 24 & 11 & 14 & 13 & 0.008 & & \\
\hline 33 & 12 & 13 & 24 & 11 & 13 & 13 & 0.008 & & \\
\hline 34 & 13 & 12 & 23 & 11 & 13 & 14 & 0.008 & & \\
\hline 35 & 14 & 12 & 24 & 11 & 13 & 14 & & 0.034 & \\
\hline 36 & 14 & 12 & 22 & 11 & 13 & 13 & & 0.034 & \\
\hline 37 & 16 & 9 & 24 & 11 & 13 & 13 & & 0.017 & \\
\hline 38 & 15 & 12 & 23 & 10 & 13 & 13 & & 0.017 & \\
\hline 39 & 14 & 12 & 26 & 11 & 13 & 12 & & 0.017 & \\
\hline 40 & 14 & 14 & 24 & 10 & 13 & 13 & & 0.017 & \\
\hline 41 & 16 & 12 & 24 & 10 & 11 & 14 & & 0.017 & \\
\hline 42 & 13 & 12 & 24 & 11 & 13 & 13 & & 0.017 & \\
\hline 43 & 14 & 12 & 24 & 10 & 13 & 14 & & 0.017 & \\
\hline 44 & 14 & 12 & 24 & 9 & 12 & 13 & & 0.017 & \\
\hline 45 & 14 & 12 & 25 & 11 & 14 & 13 & & 0.017 & \\
\hline 46 & 14 & 12 & 23 & 11 & 14 & 13 & & 0.017 & \\
\hline 47 & 15 & 12 & 25 & 10 & 11 & 13 & & & 0.010 \\
\hline 48 & 16 & 12 & 25 & 11 & 13 & 13 & & & 0.010 \\
\hline 49 & 13 & 12 & 23 & 10 & 11 & 14 & & & 0.010 \\
\hline \multicolumn{10}{|c|}{$\mathrm{Y}^{*}$ haplogroup } \\
\hline 50 & 14 & 16 & 23 & 10 & 11 & 12 & 0.008 & 0.017 & 0.010 \\
\hline 51 & 14 & 17 & 23 & 11 & 11 & 12 & & 0.017 & 0.019 \\
\hline 52 & 15 & 12 & 22 & 10 & 11 & 14 & & 0.017 & 0.010 \\
\hline 53 & 14 & 14 & 23 & 10 & 11 & 13 & 0.008 & 0.017 & \\
\hline 54 & 14 & 15 & 23 & 10 & 11 & 12 & 0.016 & & 0.010 \\
\hline 55 & 14 & 12 & 22 & 10 & 11 & 13 & 0.008 & & \\
\hline 56 & 15 & 13 & 25 & 10 & 11 & 13 & 0.008 & & \\
\hline 57 & 13 & 13 & 24 & 12 & 11 & 13 & 0.008 & & \\
\hline 58 & 17 & 13 & 23 & 10 & 11 & 13 & 0.008 & & \\
\hline 59 & 17 & 13 & 24 & 9 & 11 & 13 & 0.008 & & \\
\hline 60 & 14 & 11 & 25 & 10 & 11 & 12 & 0.008 & & \\
\hline 61 & 15 & 13 & 22 & 10 & 11 & 14 & 0.008 & & \\
\hline 62 & 15 & 15 & 23 & 9 & 11 & 13 & 0.008 & & \\
\hline 63 & 15 & 12 & 22 & 10 & 11 & 13 & 0.008 & & \\
\hline 64 & 16 & 12 & 22 & 10 & 10 & 14 & 0.008 & & \\
\hline 65 & 14 & 13 & 25 & 8 & 11 & 13 & 0.008 & & \\
\hline 66 & 13 & 12 & 23 & 10 & 11 & 13 & 0.008 & & \\
\hline 67 & 17 & 14 & 23 & 10 & 11 & 13 & 0.008 & & \\
\hline 69 & 14 & 12 & 23 & 10 & 12 & 13 & 0.008 & & \\
\hline 70 & 14 & 15 & 23 & 9 & 9 & 12 & 0.008 & & \\
\hline 71 & 14 & 12 & 24 & 11 & 13 & 13 & 0.008 & & \\
\hline 72 & 14 & 14 & 24 & 10 & 11 & 12 & & 0.034 & \\
\hline 73 & 14 & 14 & 24 & 10 & 11 & 13 & & 0.017 & \\
\hline 74 & 15 & 12 & 21 & 10 & 11 & 15 & & 0.017 & \\
\hline 75 & 15 & 15 & 23 & 11 & 11 & 12 & & 0.017 & \\
\hline 76 & 15 & 15 & 23 & 10 & 11 & 12 & & 0.017 & \\
\hline 77 & 15 & 15 & 24 & 9 & 11 & 13 & & 0.017 & \\
\hline 78 & 13 & 14 & 25 & 10 & 10 & 13 & & 0.017 & \\
\hline 79 & 15 & 17 & 23 & 11 & 11 & 12 & & & 0.010 \\
\hline 80 & 14 & 15 & 24 & 10 & 11 & 12 & & & 0.010 \\
\hline 81 & 14 & 16 & 23 & 11 & 11 & 12 & & & 0.010 \\
\hline 82 & 14 & 13 & 23 & 10 & 11 & 12 & & & 0.010 \\
\hline 83 & 14 & 18 & 24 & 11 & 11 & 12 & & & 0.010 \\
\hline
\end{tabular}




\begin{tabular}{|c|c|c|c|c|c|c|c|c|c|}
\hline \multirow[t]{2}{*}{ Haplotype } & \multicolumn{6}{|c|}{ Loci $^{2}$} & \multicolumn{3}{|c|}{ Population } \\
\hline & 1 & 2 & 3 & 4 & 5 & 6 & $\begin{array}{l}\text { Spain } \\
(124)\end{array}$ & $\begin{array}{c}\text { Gran Canaria } \\
(59) \\
\end{array}$ & $\begin{array}{c}\text { Berbers } \\
(104)\end{array}$ \\
\hline \multicolumn{10}{|c|}{ DE-YAP* haplogroup } \\
\hline 84 & 13 & 12 & 24 & 9 & 11 & 13 & 0.024 & 0.068 & 0.274 \\
\hline 85 & 13 & 12 & 24 & 10 & 11 & 13 & 0.016 & 0.051 & 0.038 \\
\hline 86 & 13 & 12 & 23 & 9 & 11 & 13 & & 0.017 & 0.100 \\
\hline 87 & 13 & 12 & 25 & 10 & 11 & 14 & & 0.017 & 0.010 \\
\hline 88 & 14 & 15 & 22 & 10 & 11 & 12 & 0.008 & & 0.010 \\
\hline 89 & 14 & 12 & 24 & 10 & 11 & 13 & & & 0.010 \\
\hline 90 & 13 & 12 & 23 & 10 & 11 & 13 & 0.008 & & \\
\hline 91 & 14 & 12 & 24 & 11 & 13 & 13 & 0.008 & & \\
\hline 92 & 13 & 13 & 24 & 9 & 11 & 13 & & & 0.067 \\
\hline 93 & 13 & 12 & 25 & 9 & 11 & 13 & & & 0.038 \\
\hline 94 & 13 & 12 & 22 & 9 & 11 & 13 & & & 0.038 \\
\hline 95 & 13 & 12 & 24 & 9 & 11 & 14 & & & 0.019 \\
\hline 96 & 16 & 12 & 24 & 10 & 11 & 13 & & & 0.019 \\
\hline 97 & 12 & 12 & 24 & 10 & 11 & 13 & & & 0.010 \\
\hline 98 & 13 & 13 & 23 & 9 & 11 & 13 & & & 0.010 \\
\hline 99 & 13 & 13 & 22 & 9 & 11 & 13 & & & 0.010 \\
\hline 100 & 13 & 12 & 25 & 9 & 11 & 12 & & & 0.010 \\
\hline 101 & 13 & 12 & 24 & 9 & 11 & 12 & & & 0.010 \\
\hline 102 & 14 & 12 & 22 & 9 & 11 & 13 & & & 0.010 \\
\hline 103 & 14 & 12 & 24 & 9 & 11 & 13 & & & 0.038 \\
\hline 104 & 13 & 12 & 23 & 8 & 11 & 13 & & & 0.010 \\
\hline 105 & 15 & 12 & 24 & 10 & 11 & 13 & & & 0.010 \\
\hline 106 & 13 & 13 & 25 & 10 & 11 & 13 & & & 0.010 \\
\hline 107 & 16 & 12 & 24 & 9 & 11 & 13 & & & 0.010 \\
\hline 108 & 16 & 12 & 21 & 10 & 11 & 14 & & & 0.010 \\
\hline 109 & 13 & 12 & 24 & 10 & 10 & 13 & & & 0.010 \\
\hline 110 & 13 & 12 & 24 & 11 & 11 & 13 & & & 0.010 \\
\hline 111 & 13 & 12 & 23 & 10 & 11 & 14 & & & 0.010 \\
\hline 112 & 13 & 12 & 25 & 10 & 11 & 13 & & & 0.010 \\
\hline 113 & 15 & 12 & 25 & 10 & 11 & 13 & & & 0.010 \\
\hline 114 & 14 & 12 & 22 & 10 & 11 & 13 & & & 0.010 \\
\hline \multicolumn{10}{|c|}{ E-M2 haplogroup } \\
\hline 115 & 17 & 12 & 21 & 10 & 11 & 14 & & & 0.010 \\
\hline 116 & 16 & 12 & 21 & 10 & 11 & 14 & & & 0.010 \\
\hline 117 & 16 & 12 & 21 & 10 & 11 & 15 & & & 0.010 \\
\hline 118 & 14 & 12 & 21 & 10 & 11 & 13 & & & 0.010 \\
\hline
\end{tabular}

${ }^{1}$ North African Berber and Spanish samples include individuals typed by us (60 North African Berbers and 46 Spanish) and data (44 North African Berbers, and 78 Spanish) reported by Pérez-Lezaun et al. (1997) and Bosch et al. (1999).

${ }^{2} 1$ = DYS19, 2 = DYS388, 3 = DYS390, 4 = DYS391, 5 = DYS392, 6 = DYS393). Alleles are numbered according to the number of repeats (Kayser $e$ t al . 1997). In five instances identical haplotypes occurred in a different haplogroup background: 1 (P-92R7*) $71\left(\mathrm{Y}^{*}\right)=91(\mathrm{DE}-\mathrm{YAP} *) ; 10\left(\mathrm{P}-92 \mathrm{R} 7^{*}\right)=89$ $\left(\right.$ DE-YAP*); $11(\mathrm{P}-92 \mathrm{R} 7 *)=82\left(\mathrm{Y}^{*}\right) ; 47(\mathrm{P}-92 \mathrm{R} 7 *)=113(\mathrm{DE}-\mathrm{YAP} *)$; and $55\left(\mathrm{Y}^{*}\right)=114(\mathrm{DE}-\mathrm{YAP} *)$

Canarian haplotypes shown in Table 2 is found in the available data for Sub-Saharan Africans (Jorde et al., 2000), which refers mostly to Bantu-speaking populations. Among the haplotypes classified as belonging to haplogroup P-92R7*, n. 1 is the most frequent in both Gran Canarian and Spanish individuals, whereas it was not observed in the Berber sample. This haplotype and its onestep derivatives represent $32 \%$ of the chromosomes typed in Gran Canarians, and 35\% of the Spanish chromosomes, but no such chromosomes were found among the North African Berbers. Haplotype 84 and its one-step neighbors, on aggregate, have a frequency of $41 \%$ among North African Berbers, $14 \%$ in Gran Canarians, and $4 \%$ in Spaniards. In the $\mathrm{Y}^{*}$ haplogroup, no haplotype presents a frequency higher than $3.5 \%$ in the three populations. However, a pair-wise comparison of haplotypes within this lineage revealed a cluster of one-step neighbors characterized by more than 14 repeat number alleles at locus DYS388. This group of haplotypes has a frequency of $4 \%$ in Spanish, $8 \%$ in Canarian, and $8 \%$ among the Berber subjects.

Our estimates of admixture were based on the information furnished in Table 2 and on the least squares ap- 
proximation (Long, 1991). Due to the large number of microsatellite haplotypes identified, the data of Table 2 could not be used directly for this purpose. Instead, we defined ten categories of $\mathrm{Y}$ haplotypes for this analysis. Two categories were defined from each of haplogroups P-92R7* and DE-YAP*, one including the modal haplotypes and their one-step neighbors, and another including all the other haplotypes detected in each haplogroup. In haplogroup $\mathrm{Y}^{*}$ no modal haplotype was identified, however five haplotype clusters could be defined by grouping together one-step neighbors. Finally, the four chromosomes distinguished in haplogroup E-M2 were considered as a single category.

Combining our data with that reported in the literature (Pérez-Lezaun et al., 1997; Bosch et al., 1999; Jorde et al., 2000), we obtained the parental population Y-haplotype frequencies to be used in the admixture analysis, using 10 haplotype groups defined as detailed above. Parental contributions in Gran Canarians are $82 \% \pm 6 \%$ Spanish and $18 \% \pm 6 \%$ Berber; a Sub-Saharan African contribution was not detectable. These values are of the same order of magnitude as those obtained in an earlier study carried out with another set of Y-markers but with the same admixture analysis method, which estimated these contributions as being $90 \% \pm 4 \%, 9 \% \pm 4 \%$, and $1 \% \pm 1 \%$, respectively (Flores et al., 2003).

Table 3 shows a compilation of admixture results, using bi and uniparental markers for Gran Canaria and Colombia, another population showing native-immigrant admixture as a result of the Spanish colonial expansion of the $16^{\text {th }}$ century (Carvajal-Carmona et al., 2000). The values for the Y-chromosomes of Gran Canarian islanders are about $86 \%$ Spanish, 14\% Berber, and 1\% Sub-Saharan African, whereas for mtDNA the numbers are $45 \% \pm 20 \%$ Spanish and 55\% $\pm 20 \%$ Berber. An earlier study also employing mtDNA haplogroup frequencies and a similar least-squares method (Elston, 1971) obtained similar estimates for Canarian islanders as a whole, namely $43 \%$ from the Iberian Peninsula and 57\% from North African Berbers (Flores et al., 2001).

It is interesting to contrast the admixture history of Gran Canarians with that of Colombians. In these two populations, the estimates of Spanish ancestry are much higher for the Y-chromosome $(85 \%, 93 \%)$ than for mtDNA (45\%, $1 \%$ ), indicating a preferential mating between Spanish men and native women. This pattern seems to represent a general one at the founding of the colonial populations of the former Spanish Empire, and most likely relates to the preferentially male migration from Spain to the colonies, particularly during the early stages of the Empire (BoydBowman, 1976). Although in both Colombia and Gran Canaria the mtDNA markers reveal a larger native component than the Y-chromosome, this relationship is much more marked in Colombians. The larger proportion of Spanish mtDNA lineages in Gran Canarians suggests that a relatively larger fraction of Spanish women arrived there
Table 3 - Parental contribution in Gran Canarian and Colombian populations based on autosomal, Y-chromosome and mtDNA data sets.

\begin{tabular}{|c|c|c|c|}
\hline \multirow{2}{*}{$\begin{array}{l}\text { Population } \\
\text { Type of marker }\end{array}$} & \multicolumn{3}{|c|}{ Parental contribution } \\
\hline & Spain & Natives $^{1}$ & Sub-Saharan Africa \\
\hline \multicolumn{4}{|l|}{ Gran Canaria } \\
\hline Autosomes $^{2}$ & 72 & 22 & 6 \\
\hline $\mathrm{MtDNA}^{3}$ & 45 & 55 & 0 \\
\hline Y-chromosomes ${ }^{4}$ & 86 & 14 & $<1$ \\
\hline \multicolumn{4}{|l|}{ Colombia $^{5}$} \\
\hline Autosomes & 75 & 15 & 15 \\
\hline mtDNA & 1 & 91 & 8 \\
\hline Y-chromosomes & 93 & 4 & 3 \\
\hline
\end{tabular}

${ }^{1}$ Guanche (Berber) for Gran Canarians, and Native Americans for Colombian populations.

${ }^{2}$ Compiled from Roberts et al. (1966).

${ }^{3}$ Values calculated by us from mtDNA haplogroup frequencies furnished by Flores et al. (2001), using Long's least square method.

${ }^{4}$ Arithmetic mean values calculated from our admixture numbers and those obtained by Flores et al (2003).

${ }^{5}$ Data of Carvajal-Carmona et al.(2000) and Carvajal-Carmona et al. (unpublished).

than in Colombia. This is consistent with a scenario of Spanish women concentrating in areas of easier access during the colonial expansion, particularly along the maritime travel routes (the Colombian sample was obtained in the state of Antioquia, a mountainous inland region of Colombia). Furthermore, the greater geographic proximity of the Canary Islands to the Spanish mainland and its continuing political integration with Spain are likely to have facilitated more recent migrations, with a higher proportion of women as compared to earlier periods. On the other hand, Colombia separated from Spain in the early $19^{\text {th }}$ century and has received little foreign immigration since then.

In both Gran Canaria and Colombia, the autosome estimates of parental contributions showed in general the expected intermediate values from the other two, although they do not show exactly midpoint numbers, probably due to sampling or other random factors.

These data demonstrate that, although some heterogeneity can exist, there is a usual trend in the Spanish colonial history, characterized by a demographic collapse of the aboriginal population, but with considerable introgression of genes through native women. Similar results were observed with regard to the Portuguese conquest of Brazil (Alves-Silva et al., 2000; Carvalho-Silva et al., 2001). These events caused the contemporary hybrid people subjected to this process to present a mosaic genome. Their Y-chromosomes have mainly been transplanted from outside; their mtDNA, however, received much less outside influences, like the witness people in Ribeiros $(1970,1977)$ typology, who had not been much influenced by the conquerors. The witness mtDNA genome terminology is also adequate, since it indicates a unique possibility of rescuing 
part of the lost history of the extinct aboriginal groups. Finally, their autosome sets were considerably shuffled, as the new peoples arose by a process of acculturation and fusion of European, native and African contributions.

\section{Acknowledgements}

We are very grateful to the individuals who donated samples for this study, and thank Luis G. Carvajal-Carmona for stimulating discussions. Special acknowledgement is due to F. Sánchez-García, J.C. Rodríguez-Gallego and M.C. Déniz-Naranjo for the Gran Canarian, and J.M. Soria, J.L. Pérez-Arellano and A.S. Auñon for the Spanish samples. MCB was a Wellcome Trust Travelling Research Fellow (Grant 059763 to M-C B and A. R-L) during 20002001. LC is supported by a BBSRC grant (31/G13580) to Ziheng Yang (University College London).

\section{References}

Alves-Silva J, Santos MS, Guimarães PM, Ferreira ACS, Bandelt H-J, Pena SDJ and Prado VF (2000) The ancestry of Brazilian mtDNA lineages. Am J Hum Genet 67:444-461.

Bortolini MC, Salzano FM, Bau C, Layrisse Z, Petzl-Erler ML, Tsuneto LT, Hill K, Hurtado AM, Castro-De-Guerra D, Bedoya G and Ruiz-Linares A (2002) Y-chromosome biallelic polymorphisms and Native American population structure. Ann Hum Genet 66:255-259.

Bortolini MC, Salzano FM, Thomas M, Nasanen SPK, Bau CHD, Hutz MH, Layrisse Z, Petzl-Erler ML, Tsuneto LT, Hill K, Hurtado AM, Castro-De-Guerra D, Torres MM, Groot H, Michalski R, Nymadawa P, Bedoya G, Bradman N, Labuda D and Ruiz-Linares A (2003) Y-chromosome evidence for differing ancient demographic histories in the Americas. Am J Hum Genet 73:524-539.

Bosch E, Calafell F, Santos FR, Perez-Lezaun A, Comas D, Benchemsi N, Tyler-Smith C and Bertranpetit J (1999) Variation in short tandem repeats is deeply structured by genetic background on the human Y chromosome. Am J Hum Genet 65:1623-1638.

Boyd-Bowman P (1976) Patterns of Spanish emigration to the Indies until 1600. Hisp Am Hist Rev 66:580-604.

Carvajal-Carmona LG, Soto ID, Pineda N, Ortíz-Barrientos D, Duque C, Ospina-Duque J, McCarthy M, Montoya P, Alvarez VM, Bedoya G and Ruiz-Linares A (2000) Strong Amerind/White sex bias and a possible Sephardic contribution among the founders of a population in Northwest Colombia. Am J Hum Genet 67:1287-1295.

Carvalho-Silva DR, Santos FR, Rocha J and Pena SDJ (2001) The phylogeography of Brazilian Y-chromosome lineages. Am J Hum Genet 68:281-286.

Castro-De-Guerra D, Arroyo E, Salzano FM and Bortolini MC (2003) Transplanted male genomes in three Venezuelan populations. Interciencia 28:197-201.

Curtin PD (1969) The Atlantic slave trade: a Census. The University of Wisconsin Press, Madison.

Elston RC (1971) The estimation of admixture in racial hybrids. Ann Hum Genet 35:9-17.

Esteban E, Dugoujon JM, Valeny N, Gonzale-Reimers E and Moral P (1998) Spanish and African contributions to the ge- netic pool of the Canary islanders: data from GM and KM haplotypes and RFLPs in the immunoglobulin IGHG. Ann Hum Genet 62:33-45.

Férnandez-Armesto F (1982) The Canary Island after the conquest. The making of a colonial society in the Sixteenth Century. Clarendon Press, Oxford.

Flores C, Larruga JM, González AM, Hernández M, Pinto F and Cabrera VM (2001) The origin of the Canary Island aborigines and their contribution to the modern population: a molecular genetics perspective. Curr Anthropol 42:749-755.

Flores C, Maca-Meyer N, Pérez JÁ, González AM, Larruga JM and Cabrera VM (2003) A predominant European ancestry of parental lineages from Canary Islanders. Ann Hum Genet 67:138-152.

Hammer MF and Horai S (1995) Y chromosome DNA variation and the peopling of Japan. Am J Hum Genet 56:951-962.

Hammer MF, Spurdle AB, Karafet T, Bonner MR, Wood ET, Novelletto A and Malaspina P (1997) The geographical distribution of human $\mathrm{Y}$ chromosome variation. Genetics 145:787-805.

Hurles ME, Irven C, Nicholson J, Tylor PG, Santos FR, Loughlin J, Jobling MA and Sykes BC (1998) European Y-chromosomal lineages in Polynesians: a contrast to the population structure revealed by mtDNA. Am J Hum Genet 63:17931806.

Jorde LB, Watkins WS, Bamshad MJ, Dixon ME, Ricker CE, Seielstad MT and Batzer MA (2000) The distribution of human genetic diversity: a comparison of mitochondrial, autosomal, and Y-chromosome data. Am J Hum Genet 66:979-988.

Kayser M, Cagliá A, Corah D, Fretwell N, Gehring C, Graziosi G, Heidorn F, Herrmann S, Herzog B, Hidding M, Honda K, Jobling M, Krawezak M, Leim K, Meuser S, Meyer E, Oesterreich W, Pandya A, Parson W, Penacino G, PerézLezaun A, Piccinini A, Prinz M, Schmitt C, Schneider PM, Szibor R, Teifel-Greding J, Weichhold G, Knijff P and Roewer L (1997) Evaluation of Y-chromosomal STRs: a multicenter study. Int J Legal Med 110:125-133.

Kayser M, Brauer S, Weiss G, Schiefenhövel W, Underhill P, Shen P, Oefner P, Tommaseo-Panzetta M and Stoneking M (2003) Reduced Y-chromosome, but not mitochondrial DNA, diversity in human populations from West New Guinea. Am J Hum Genet 72:281-302.

Long JC (1991) The genetic structure of admixed populations. Genetics 127:417-428.

Murdock GP (1959) Africa: its people and their culture history. McGraw-Hill, New York.

Pérez-Lezaun A, Calafell F, Seielstad M, Mateu E, Comas D, Bosch E and Bertranpetit J (1997) Population genetics of Y-chromosome short tandem repeats in humans. J Mol Evol 45:265-270

Rando JC, Cabrera VM, Larruga JM, Hernández M, González AM, Pinto F and Bandelt H-J (1999) Phylogeographic patterns of mtDNA reflecting the colonization of the Canary Islands. Ann Hum Genet 63:413-428.

Ribeiro D (1970) The culture-historical configurations of the American peoples. Current Anthropol 11:403-434.

Ribeiro D (1977) As américas e a civilização. Editora Vozes, Petrópolis. 
Roberts DF, Evans M, Ikin EW and Mourant AE (1966) Blood groups and the affinities of the Canary Islanders. Man $1: 512-525$.

Salzano FM and Bortolini MC (2002) Evolution and genetics of Latin American populations. Cambridge University Press, Cambridge.

Schneider S, Roessli D and Excoffier L (2000) ARLEQUIN version 2000: a software for population genetic data analysis. Genetic and Biometry Laboratory, Geneva.

Seielstad MT, Hebert JM, Lin AA, Underhill PA, Ibrahim M, Vollrath D and Cavalli-Sforza LL (1994) Construction of human Y-chromosome haplotypes using a new polymorphic A to G transition. Hum Mol Genet 3:2159-2161.

Schwidetzy I (1963). La poblácion prehistórica de las Islas Canarias. Publicaciones del Museo Arqueológico, Santa Cruz de Tenerife.

Thomas MG, Bradman N and Flinn HM (1999) High throughput analysis of 10 microsatellite and 11 diallelic polymorphisms on the human Y-chromosome. Hum Genet 105:577-581.

Thomas MG, Parfitt T, Weiss DA, Skorecki K, Wilson JF, le Roux M, Bradman N and Goldstein D (2000) Y chromosome traveling south: the Cohen model haplotype and the origin of the Lemba - the "Black Jews of Southern Africa". Am J Hum Genet. 66:678-686.
Underhill PA, Jin L, Lin AA, Mehdi SQ, Jenkins T, Vollrath D, Davis RW, Cavalli-Sforza LL and Oefner PJ (1997) Detection of numerous $\mathrm{Y}$ chromosome biallelic polymorphisms by denaturating high-performace liquid chromatography. Genome Res 7:996-1005.

Underhill PA, Shen P, Lin AA, Jin L, Passarino G, Yang WH, Kauffmann E, Bonné-Tamir B, Bertranpetit J, Francalacci P, Ibrahim M, Jenkins T, Kidd JR, Mehdi SQ, Seielstad MT, Wells RS, Piazza A, Davis RW, Feldman MW, CavalliSforza LL and Oefner OJ (2000) Y chromosome sequence variation and the history of human populations. Nature Genet 26:358-361.

Underhill PA, Passarino G, Lin AA, Shen P, Lahr MM, Foley RA, Oefner PJ and Cavalli-Sforza LL (2001) The phylogeography of Y chromosome binary haplotypes and the origin of modern human populations. Am J Hum Genet 65:43-62.

Velasco-Vásquez J, González-Reimers E, Arnay-De-La-Rosa M, Barros-Lopez N, Martin-Rodriguez E and SantolariaFernández F (1999) Bone histology of prehistoric inhabitants of the Canary Islands: comparison between El Hierro and Gran Canaria. Am J Phys Anthropol 110:201-213.

Y Chromosome Consortium (2002) A nomenclature system for the tree of human Y-chromosomal binary haplogroups. Gen Res 12:339-348.

Editor: Angela M. Vianna-Morgante

Appendix - Data obtained in the present study.

\begin{tabular}{|c|c|c|c|}
\hline Population & SNP-haplogroup & No. of chromosomes & STR-haplotypes ${ }^{1}$ (no. of chromosomes) \\
\hline \multirow[t]{3}{*}{ Gran Canaria } & P-92R7* & 38 & $\begin{array}{l}1(10) ; 2(4) ; 3(3) ; 4(2) ; 5(1) ; 6(1) ; 7(1) ; 8(1) ; 9(1) ; 35(2) ; 36(2) \text {; } \\
37(1) ; 38(1) ; 39(1) ; 40(1) ; 41(1) ; 42(1) ; 43(1) ; 44(1) ; 45(1) ; \\
46(1)\end{array}$ \\
\hline & $\mathrm{Y}^{*}$ & 12 & $\begin{array}{l}50(1) ; 51(1) ; 52(1) ; 53(1) ; 72(2) ; 73(1) ; 74(1) ; 75(1) ; 76(1) \\
77(1) ; 78(1)\end{array}$ \\
\hline & DE-YAP* & 9 & $84(4) ; 85(3) ; 86(1) ; 87(1)$ \\
\hline \multirow[t]{3}{*}{ Spain } & $\mathrm{P}-92 \mathrm{R} 7 *$ & 31 & $\begin{array}{l}1(5) ; 2(5) ; 5(2) ; 7(1) ; 9(1) ; 10(3) ; 11(1) ; 12(2) ; 13(3) ; 14(1) \\
28(1) ; 29(1) ; 30(1) ; 31(1) ; 32(1) ; 33(1) ; 34(1)\end{array}$ \\
\hline & $\mathrm{Y}^{*}$ & 10 & $50(1) ; 53(1) ; 54(2) ; 55(1) ; 64(1) ; 65(1) ; 67(1) ; 69(1) ; 70(1)$ \\
\hline & DE-YAP* & 5 & $84(2) ; 85(1) ; 90(1) ; 91(1)$ \\
\hline \multirow[t]{4}{*}{ Berber } & $\mathrm{P}-92 \mathrm{R} 7 *$ & 1 & $47(1)$ \\
\hline & $\mathrm{Y}^{*}$ & 4 & $52(1) ; 79(1) ; 81(1) ; 82(1)$ \\
\hline & DE-YAP* & 51 & $\begin{array}{l}84(21) ; 85(2) ; 86(5) ; 87(1) ; 88(1) ; 89(1) ; 92(6) ; 93(3) ; 94(1) ; \\
95(1) ; 96(2) ; 97(1) ; 98(1) ; 99(1) ; 100(1) ; 101(1) ; 102(1) \\
\text { 114(1) }\end{array}$ \\
\hline & E-M2 & 4 & $115(1) ; 116(1) ; 117(1) ; 118(1)$ \\
\hline
\end{tabular}

${ }^{1}$ Haplotype numbers according to Table 2 . 